\title{
Howard Zinn: A Public Intellectual Who Mattered
}

\author{
Henry A. Giroux
}

In 1977 I took my first job in higher education at Boston University. One reason I went there was because Howard Zinn was teaching at Boston University at the time. As a high school teacher, Howard's book, Vietnam: the Logic of Withdrawal, published in 1968, had a profound effect on me. Not only was it infused with a passion and sense of commitment that I admired as a high school teacher and tried to internalize as part of my own pedagogy, but it captured something about the passion, sense of commitment, and respect for solidarity that came out of Howard's working-class background. It offered me a language, history, and politics that allowed me to engage critically and articulate my opposition to the war that was raging at the time. I grew up in Providence, RI and rarely met or read any working class intellectuals. After reading James Baldwin, hearing William Kunstler and Stanley Aronowitz give talks, I caught a glimpse of what it meant to occupy such a fragile, contradictory, and often scorned location. But reading Howard gave me the theoretical tools to understand more clearly how the mix of biography, cultural capital, and class location could be finely honed into a viable and laudable politics.

Later as I got to know Howard personally, I was able to fill in the details about his working-class background and his intellectual development. We had grown up in similar neighborhoods, shared a similar cultural capital, and we both probably learned more from the streets than we had ever learned in formal schooling. There was something about Howard's fearlessness, his courage, his willingness to risk not just his academic position, but also his life that marked him as special-untainted by the often corrupting privileges of class entitlement.

Before I arrived in Boston to begin teaching at Boston University, Howard was a mythic figure for me and I was anxious to meet him in real life. How I first encountered him was perfectly suited to the myth. While walking to my first class, as I was nearing the university, filled with the trepidation of teaching a classroom of students, I caught my fist glimpse of Howard. He was standing on a box with a bullhorn in front of the Martin Luther King memorial giving a talk calling for opposition and resistance to the Vietnam War. The image so perfectly matched my own understanding of Howard that I remember thinking to myself "that this has to be the perfect introduction to such a heroic figure." Soon afterwards, I wrote him a note and rather sheepishly asked if we could meet. He got back to me in a day: we went out to lunch soon afterwards, and a friendship developed that lasted over thirty years. While teaching at Boston University, I often accompanied Howard when he went to high schools to talk about his published work or his plays. I sat in on many of his lectures and even taught one of his graduate courses. He loved talking to students and they were equally attracted to him. His pedagogy was dynamic, directive, focused, laced with humor, and always open to dialogue and interpretation. He was a magnificent teacher, who shredded all notions of the classroom as a place that was as uninteresting as it was often irrelevant to larger social concerns. He urged his students not just to learn from history but to use it as a resource to sharpen their intellectual prowess and horn their civic responsibilities. Howard refused to separate what he taught in the university classroom or any forum for that matter from the most important problems and issues facing the larger society. But he never demanded that students follow his own actions; he simply provided a model of what a combination of what knowledge, teaching, social commitment meant. Central to Howard's pedagogy was the belief that teaching students how to be critical or understand a text or any other form of knowledge was not enough. They also had to engage such knowledge as part of a broader engagement with matters of civic agency and social responsibility. How they did that was up to them, but most importantly they had to 
link what they learned to a self-reflective understanding of their own responsibility as engaged individuals and social actors. He offered students a range of options: he wasn't interested in molding students in the manner of Pygmalion, but in giving them the widest possible set of choices and knowledge necessary for them to view what they learned as an act of freedom and empowerment. There is a certain poetry in his pedagogical style and scholarship, and it is captured in his belief that one can take a position without standing still. He captures this sentiment well in a comment he made in his autobiography, You Can't Be Neutral on a Moving Train. He writes: "From the start, my teaching was infused with my own history. I would try to be fair to other points of view, but I wanted more than 'objectivity'; I wanted students to leave my classes not just better informed, but more prepared to relinquish the safety of silence, more prepared to speak up, to act against injustice wherever they saw it. This, of course, was a recipe for trouble.” In fact, Howard was under constant attack by Silber at Boston University because of his scholarship and teaching. One expression of that attack took the form of freezing Howard's salary for years.

Howard loved watching independent and Hollywood films, and he and I and Roz saw many films together while I was in Boston. I remember how we quarreled over Last Tango in Paris. I loved the film but he disagreed. But Howard disagreed in a way that was persuasive and instructive. He listened, stood his ground, and if he was wrong often said something like, "okay, you got a point," always accompanied by that broad and wonderful smile. What was so moving and unmistakable about Howard was his humility; his willingness to listen; his refusal of all orthodoxies; and his sense of respect for others. I remember once when he was leading a faculty strike at BU in the late 1970s, and I mentioned to him that too few people had shown up. He looked at me and made it very clear that what should be acknowledged is that some people did show up and that was a beginning. He rightly put me in my place that day-a lesson I never forgot. Howard was no soppy optimist, but someone who believed that human beings, in the face of injustice and with the necessary knowledge, were willing to resist, organize, and collectively struggle. Howard lead the committee organized to fight my firing by John Silber, the then President of Boston University. We lost that battle but Howard was a source of deep comfort and friendship for me during a time when I had given up hope. I later learned that John Silber, the notorious right-wing enemy of Howard and anyone else on the Left, had included me on a top-ten list of blacklisted academics at BU. Hearing that I shared that list with Howard was a proud moment for me. But Howard occupied a special place in Silber's list of enemies, and he once falsely accused Zinn of arson, a charge he was later forced to retract once the charge was leaked to the press.

Howard was one of the few intellectuals I have met who took education seriously. He embraced it as both necessary for creating an informed citizenry, and because he rightly felt it was crucial to the very nature of politics and human dignity. He was a deeply committed scholar and intellectual for whom the line between politics and life, teaching and civic commitment collapsed into each other. Howard never allowed himself to be seduced either by threats, the seductions of fame, or the need to tone down his position for the standard bearers of the new illiteracy that now populate the mainstream media. As an intellectual for the public, he was a model of dignity, engagement, and civic commitment. He believed that addressing human suffering and social issues mattered, and he never flinched from that belief. His commitment to justice and the voices of those expunged from the official narratives of power are evident in such works as his monumental and best-know book, A People's History of the United States, but it was also evident in many of his other works, talks, interviews, and the wide scope of public interventions that marked his long and productive life. Howard provided a model of what it meant to be an engaged scholar who was deeply committed to sustaining public values and a civic life in ways that linked theory, history, and politics to the everyday needs and language that informed everyday life. He never hid behind a fire wall of jargon, refused to substitute irony for civic courage, and disdained the assumption that working class and oppressed people were incapable of governing themselves. Unlike so many public relations intellectuals today, I never heard him interview himself while talking to others. Everything he talked about often pointed to larger social issues, and all the while, he completely rejected any vestige of political and moral purity. His lack of rigidity coupled with his warmness and humor often threw people off, especially those on the left and right who seem to pride themselves on their often zombie-like stoicism. But then again, Howard was not a child of privilege. He had a working-class sensibility, though hardly romanticized, and sympathy for the less privileged in society along with those whose voices had been kept out of the official narratives (as well as a deeply felt commitment to solidarity, justice, dialogue, and hope). And it was precisely this great sense of dignity and generosity in his politics and life that often moved people who shared his company privately or publicly. A few days before his death, he sent me an email commenting on something I had written for Truthout about zombie politics. (It astonishes me that this will have been the last correspondence. Even at my age, the encouragement and support of this man, this towering figure in my life, meant such a great deal.) His response captures something so enduring and moving about his spirit. He wrote: "Henry, we are in a situation where mild 
rebuke, even critiques we consider 'radical' are not sufficient. (Frederick Douglass' speech on the Fourth of July in 1852, thunderously angry, comes close to what is needed). Raising the temperature of our language, our indignation, is what you are doing and what is needed. I recall that Sartre, close to death, was asked: 'What do you regret?' He answered: 'I wasn't radical enough." I suspect that Howard would have said the same thing about himself. And maybe no one can ever be radical enough, but Howard came close to that ideal in his work, life, and politics. Howard's death is especially poignant for me because I think the formative culture that produced intellectuals like him is gone. He leaves an enormous gap in the lives of many thousands of people who knew him and were touched by the reality of the embodied and deeply felt politics he offered to all of us. I will miss him, his emails, his work, his smile, and his endearing presence. Of course, he would frown on such a sentiment and with a smile would more than likely say, "do more than mourn, organize." Of course, he would be right, but maybe we can do both. 
